\title{
Some brain peptides regulating the secretion of digestive enzymes in the Indian meal moth, Plodia interpunctella (Lepidoptera: Pyralidae)
}

\author{
Seyede Minoo Sajjadian*, Vahid Hosseininaveh, Khalil Talebi Jahromi
}

Department of Plant Protection, College of Agriculture and Natural Resources, University of Tehran, P.O. Box 4111, Karaj, Iran

Received: April 8, 2014

Accepted: August 6, 2014

\begin{abstract}
The Indian meal moth, Plodia interpunctella (Hübner) (Lepidoptera: Pyralidae) is a destructive polyphagous pest of many stored products. To interfere with the physiological processes, especially digestion, of the larval pest, more information on the regulatory mechanisms is needed. The brain extract from 1-day-old last instar larvae of $P$. interpunctella was examined. In the bioassays, the midguts were treated with the brain extract, and the carbohydrase and protease activities were measured. The brain extract showed increasing dose-dependent effects on $\alpha$-amylase, $\alpha$-glucosidase, $\beta$-glucosidase, $\alpha$-galactosidase, $\beta$-galactosidase, and trypsin secretion in the larval midgut. The extract was further characterised and partially purified using high performance liquid chromatography (HPLC). Several peptides were determined in the brain extract regulating hydrolase activities in the larval midgut of the pest.
\end{abstract}

Key words: digestive enzymes, HPLC, Lepidoptera, Pyralidae, regulating brain peptides

\section{Introduction}

The Indian meal moth, Plodia interpunctella (Hübner) (Lepidoptera: Pyralidae), is an important world-wide insect pest of various stored products (Mohandass et al. 2007). The pest causes significant quantitative and qualitative damage to stored products (Phillips et al. 2000). Chemical insecticides have been the primary means of controlling stored-product pests. However, because of many problems associated with the use of synthetic pesticides in integrated pest management approaches, use of chemicals to protect grains and grain products against stored-product pests is limited. More environmentallybenign alternatives are replacing chemical use (Hagstrum and Subramanyam 1996). One such approach is genetically modified plants or microorganisms bearing proteins or peptides targeting insect digestion.

In many insects, neuropeptides have been reported to exist in the brain and other nervous tissues (Verhaert and De Loof 1985). Immunological studies have shown the presence of peptides and hormones in the insect nervous system. Duve and Thorpe (1981) have reported gastrin/ cholecystokinin (CCK)-like material in the brain of the blowfly, Calliphora erythrocephala (Diptera: Calliphoridae). They also did the mapping of gastrin/cholecystokininlike peptides in the neuroendocrine system (subesophageal ganglion, thoracic ganglion, and corpus cardiacum) of the same insect species (Duve and Thorpe 1984). Immunocytochemical investigations by Verhaert and De Loof (1985) had proved the presence of P-like peptides in the central nervous system (brain, retrocerebral complex, and subesophageal ganglia) of the American cockroach, Periplaneta americana (Blattodea: Blattidae). They also reported that several substances, antigenically similar to vertebrate peptide hormones, are present in cerebral ganglia and contiguous neuronal structures of the same insect species (Verhaert et al. 1984; Verhaert and De Loof $1985,1986)$. Insulin is a peptide hormone that has important roles in regulating the cellular metabolism and growth in vertebrates (Satake et al. 1997). Application of different methods show that insulin-like peptides also exist in invertebrates such as insects (Kramer 1985). The effects of an insect insulin-related peptide, bombyxin, on the metabolism of carbohydrates in the silkworm Bombyx mori (Lepidoptera: Bombycidae) were studied by Satake et al. (1997). More than 12 neuropeptides were isolated from neurosecretory system of the Madeira cockroach Leucophaea maderae (Dictyoptera: Blattidae) and all of them, except one, apply a myotropic action (Holman et al. 1990). Leucokinins are a group of related neuropeptides that stimulate the gut motility and secretion of fluid by the Malpighian tube in insects (Harshini et al. 2002). This family of neuropeptides has been found largely among insects. A member of this family was isolated from adults of the fruit fly Drosophila melanogaster (Diptera: Drosophilidae) (Terhzaz et al. 1999). In a study by Harshini et al. (2002), the effect of leucokinins, isolated from L. maderae, their related peptide analogues, and leucopyrokinin on release of amylase and protease from the midgut epithelial cells of the larvae of Opisina arenosella (Lepidoptera: Cryptophasidae) was determined. The presence of insu- 
lin-, gastrin-, and pancreatic polypeptide-like immunoreactivity neurons in the brain of $B$. mori has been demonstrated by Yui et al. (1980). A brain peptide from the larvae of Opisina arenosella (Lepidoptera: Crytophasidae) was isolated by Harshini et al. (2003) They had partially purified this peptide and reported that it stimulates the release of amylase from the midgut tissue of the same insect species (Harshini et al. 2003).

Due to the importance of $P$. interpunctella as a serious pest insect, there has been considerable research on various aspects of the pest's developmental biology. The remarkable damage of the pest on the handling of numerous stored products makes the insect an important subject, particularly in terms of biochemical characterisation of digestive enzymes. The present study is an effort to survey the presence of brain peptides regulating the secretion of digestive enzymes such as $\alpha$-amylase, $\alpha$-glucosidase and $\beta$-glucosidase, $\alpha$-galactosidase and $\beta$-galactosidase, and trypsin in the larva midgut of $P$. interpunctella.

\section{Materials and Methods}

\section{Insects}

To establish the colony, a collection was done of adults and larvae of $P$. interpunctella from infected pistachio. The insects were reared on an artificial diet according to Sait et al. (1997) under controlled conditions at $27 \pm 1^{\circ} \mathrm{C}, 60 \pm 5 \%$ relative humidity $(\mathrm{RH})$ and 12 : $12 \mathrm{~h}$ (light : dark) photoperiod. The diet consisted of $800 \mathrm{~g}$ of wheat bran, $160 \mathrm{~g}$ dried brewer's yeast, $200 \mathrm{ml}$ honey, and $200 \mathrm{ml}$ glycerol. The fourth larval instars or 1-day-old fifth larval instars were used in all experiments.

\section{Preparation of the brain extract}

The entire head capsule of each larva was isolated and transferred into the insect saline (10-200 head capsule/ml). The insect saline ( $\mathrm{pH} 7.4)$ was composed of $130 \mathrm{mM} \mathrm{NaCl}, 5 \mathrm{mM} \mathrm{KCl}$, and $1 \mathrm{mM} \mathrm{CaCl}_{2}$ (Harshini et al. 2002). The head capsules within the insect saline were boiled for 1, 3, 5, and $10 \mathrm{~min}$ to denature the probable enzymes present. The boiled capsules were homogenised in a hand-held glass grinder and the homogenates were centrifuged at $10,000 \times \mathrm{g}$ for $10 \mathrm{~min}$. In the control, the head capsules were homogenised without boiling. The resulting supernatant was used as the incubation solution in the bioassays.

\section{Enzyme sample preparation}

The last larval instars were cold-immobilised, dissected under a stereoscopic microscope, and the midguts were removed and cleaned of unwanted adhering tissues. The midguts, including contents, were placed into $100 \mu \mathrm{l}$ distilled water and homogenised using a hand-held glass grinder on ice. The homogenates were centrifuged at $16,000 \times \mathrm{g}$ at $4^{\circ} \mathrm{C}$ for $15 \mathrm{~min}$. The supernatants were passed through filter paper (Whatman ${ }^{\circledR}$, No. 40 ), transferred to new tubes, and kept at $-20^{\circ} \mathrm{C}$ for further use.

\section{Hydrolase assay}

$\alpha$-Amylase activity was assayed according to Bernfeld (1955) using dinitrosalisylic acid (DNS) and 1\% soluble starch as the substrate with slight modifications. Briefly, $10 \mu \mathrm{l}$ enzyme extract was added to $85 \mu \mathrm{l} 40 \mathrm{mM}$ citratephosphate-borate buffer ( $\mathrm{pH} 3$ to 11 ) and $10 \mu \mathrm{l}$ of soluble starch. The experiment was stopped with the addition of $50 \mu \mathrm{l}$ DNS (44 mM) and by heating in boiling water for $10 \mathrm{~min}$. The absorbance of the reaction mixture was read at $540 \mathrm{~nm}$ using a microplate reader (ELX 808). In the blanks, the enzyme was added to the reaction mixture after the addition of DNS.

The activity of $\alpha$-glucosidase and $\beta$-glucosidase was detected according to Ramzi and Hosseininaveh (2010) and Tabatabaei et al. (2011) using $p$-nitrophenyl- $\alpha$-D-glucopyranoside $(p \mathrm{NaG}, 5 \mathrm{mM})$, and $p$-nitrophenyl- $\beta$ -D-glucopyranoside ( $p \mathrm{NbG}, 5 \mathrm{mM})$ as the substrates, respectively. The assay was carried out by incubating $10 \mu \mathrm{l}$ of the enzyme extract with $85 \mu \mathrm{l}$ of $40 \mathrm{mM}$ citrate-phosphate-borate buffer ( $\mathrm{pH} 3$ to 11), and $5 \mu \mathrm{l}$ of the substrates for $30 \mathrm{~min}$. The reaction was stopped by adding $50 \mu \mathrm{l}$ of $\mathrm{NaOH}(1 \mathrm{M})$. The optical density was measured at $405 \mathrm{~nm}$ using a microplate reader (ELX 808). In the controls, the enzyme was added to the reaction mixture after the addition of $\mathrm{NaOH}$. The same procedure was used for the measurement of $\alpha$-galactosidase and $\beta$-galactosidase activity but with the substrates $p$-nitrophenyl- $\alpha$-D-galactoside $(p \mathrm{NP} \alpha \mathrm{Gal}, 5 \mathrm{mM})$, and $p$-nitrophenyl- $\beta$-D-galactoside ( $p$ NP $\beta$ Gal, $5 \mathrm{mM})$, respectively.

Trypsin activity was determined using BApNA $\left(\mathrm{N}_{\alpha}-\right.$ -benzoyl-L-arginine- $p$-nitroanilide, $20 \mathrm{mM}$ ) as the substrate. For determining trypsin enzyme activity, $5 \mu \mathrm{l}$ of the substrate was added to $10 \mu \mathrm{l}$ of the enzyme extract and $85 \mu \mathrm{l}$ of the $40 \mathrm{mM}$ citrate-phosphate-borate buffer at $\mathrm{pH} 6$ to $\mathrm{pH} 11$. The absorbance was measured continuously for $30 \mathrm{~min}$ with a time interval of $3 \mathrm{~min}$ at $405 \mathrm{~nm}$.

\section{Bioassay}

To study the effects of the brain extract on the secretion of digestive enzymes, the whole alimentary canal of each larva was removed. The alimentary canal was transferred in a small volume of insect saline. Two ends of the midgut were tightly ligated with floss fibers, and the foregut and the hindgut were cut and discarded. One hundred ligated midguts were transferred to a petri dish $(5 \mathrm{~cm}$ diameter $)$ which held $5 \mathrm{ml}$ of insect saline and $1 \mathrm{ml}$ of the brain extract. During the incubation, a small stream of oxygen was bubbled into the solution. The bioassay apparatus was kept in a water bath at $37^{\circ} \mathrm{C}$. In the controls, one milliliter of distilled water was used instead of the brain extract. The ligated midguts were homogenised and centrifuged. The resulted supernatants were used as the enzyme source in subsequent experiments. To prove the claim that the differences in the secretion of the enzymes come from the regulatory impact of the brain extract, the enzymatic activity of both boiled and non-boiled brain extract was also studied.

In the dose-response assay, the brain extract at concentrations of 10, 50, 100, and 200 head capsules in $1 \mathrm{ml}$ insect saline was prepared. The effects of the different 
concentrations of the brain extract on the secretion of digestive enzymes were bioassayed and were compared with the control.

\section{High-performance liquid chromatography (HPLC) fractionation}

The heads of 1,000 larvae were homogenised in $5 \mathrm{ml}$ of cold $\mathrm{NaCl}(2 \%, \mathrm{w} / \mathrm{v})$. The homogenates were centrifuged at $16,000 \times \mathrm{g}$ for $15 \mathrm{~min}$. Ice-cold acetone was then added to the resulted supernatants at a final saturation level of $70 \%$ aqueous acetone and maintained at $4^{\circ} \mathrm{C}$ for $90 \mathrm{~min}$. The solution was centrifuged at $10,000 \times \mathrm{g}$ for $20 \mathrm{~min}$ at $4^{\circ} \mathrm{C}$, and ice-cold acetone was added to the supernatant at a final saturation level of $80 \%$ aqueous acetone. After a few hours at $4^{\circ} \mathrm{C}$, the microtubes were centrifuged at 18,000 $\times \mathrm{g}$ for $20 \mathrm{~min}$ at $4^{\circ} \mathrm{C}$. The precipitates were collected in the distilled water (HPLC grade) and were injected into the HPLC according to Harshini et al. (2003). In the case of the control, the entire process of preparing the brain peptides was performed on distilled water. The conditions for HPLC operating was configured as following:

- Stationary phase: C18 column, $4.6 \mathrm{~mm} \times 25 \mathrm{~cm}$;

- Mobile phase: Solvent A - 0.01 M ammonium acetate buffer ( $\mathrm{pH}$ 6.1); Solvent $\mathrm{B}-25 \%$ acetonitrile in water, according to the following time table:

\begin{tabular}{ccc}
\hline Time $[\mathrm{min}]$ & Solvent A $[\mathrm{ml}]$ & Solvent B [ml] \\
\hline 0 & 100 & 0 \\
8 & 100 & 0 \\
38 & 75 & 25 \\
60 & 25 & 75 \\
65 & 100 & 0 \\
\hline
\end{tabular}
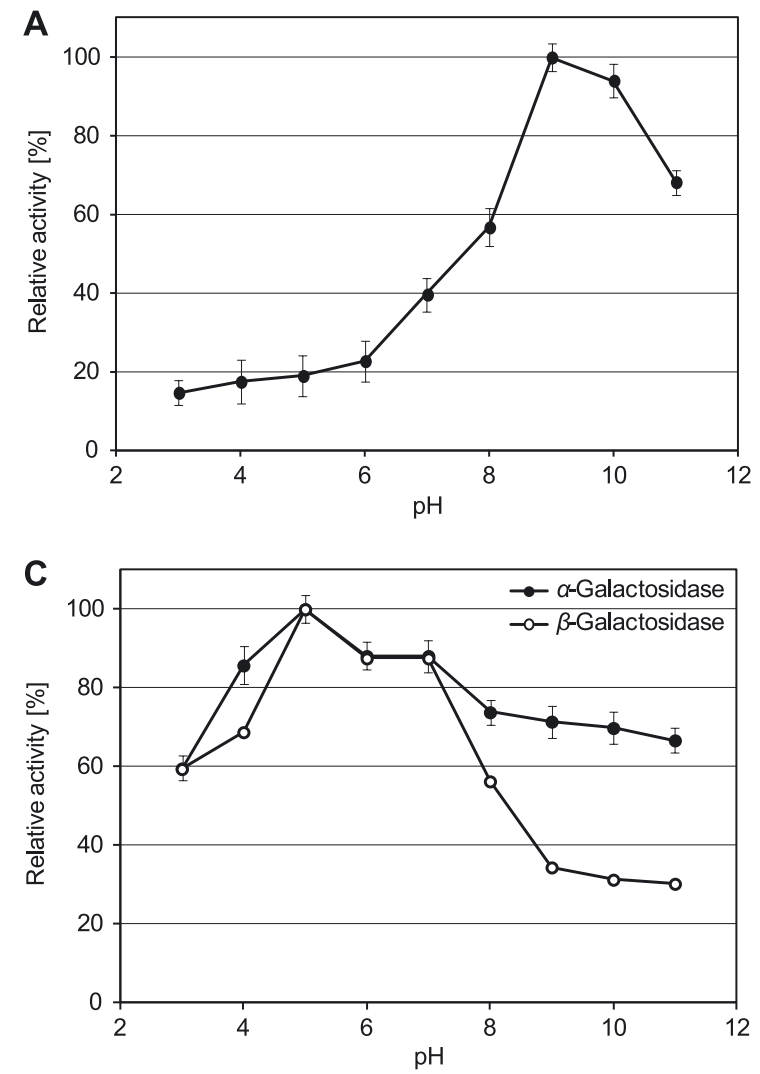

- Flow rate: $1.25 \mathrm{ml} / \mathrm{min}$;

- Operating temperature: $40^{\circ} \mathrm{C}$;

- Detector range: 0.00299 AU at $214 \mathrm{~nm}$.

After the injection of the brain extract to the HPLC, the output liquid from the device was collected in the $1.5 \mathrm{ml}$ microtubes every minute. According to the chromatograph, putative fractions bearing peptides were chosen (fractions number 9, 13, 16, 20, and 24). The putative fractions were diluted to $10 \%$ in the insect saline. The effect of the fractions was studied on the secretion of digestive trypsin and $\beta$-glucosidase as described before. A sample containing the insect saline was used as the control. A sample containing $50 \%$ acetonitrile was also used in the bioassays.

\section{Statistical analysis}

Data were analysed using STATGRAPHICS computer software, Version 5.1. Independent $t$-tests were used to compare the average of the treatments and controls. The software SigmaPlot ${ }^{\circledR}$ Version 10.0 was used to plot the graphs.

\section{Results}

\section{Hydrolase activity}

The greatest $\alpha$-amylase (Fig. 1a) and trypsin (Fig. 1d) activity of the larval midgut of $P$. interpunctella was obtained at a $\mathrm{pH}$ of 9.0. However, $\alpha$-glucosidase and $\beta$-glucosidase activity was optimum at a pH of 6.0 (Fig. 1b). Optimal $\alpha$-galactosidase and $\beta$-galactosidase activity occurred at a pH of 5.0 (Fig. 1c).
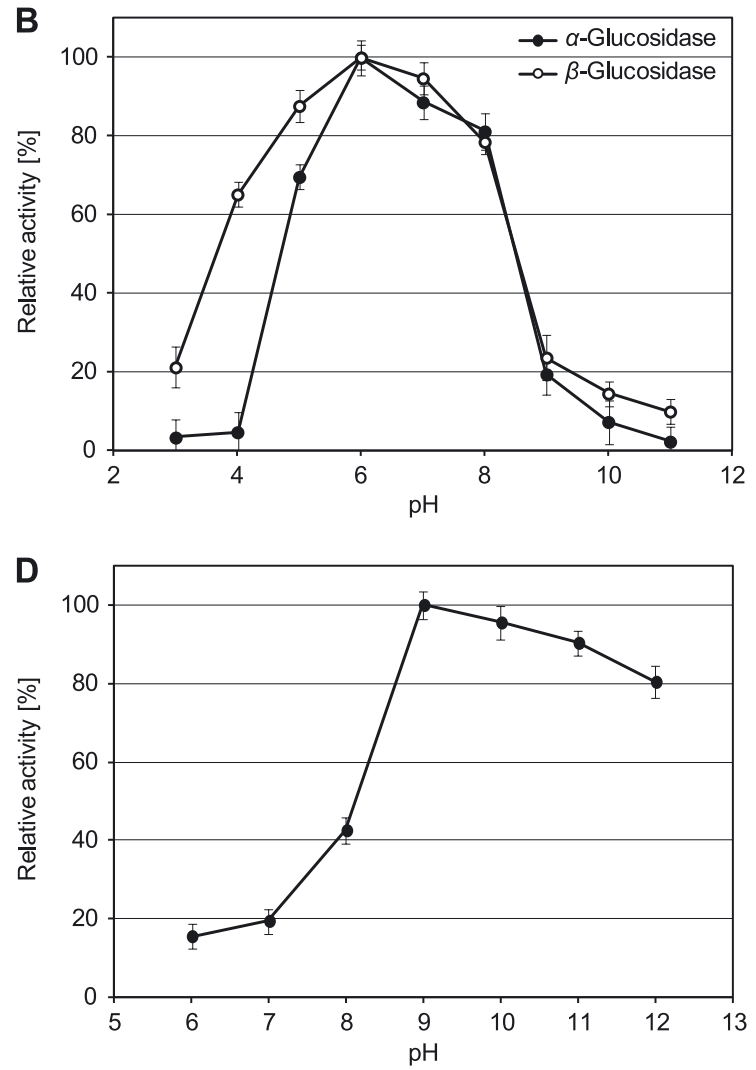

Fig. 1. The effect of $\mathrm{pH}$ on the activity of $\alpha$-amylase (A), $\alpha$-glucosidase and $\beta$-glucosidase (B), $\alpha$-galactosidase and $\beta$-galactosidase (C), and trypsin (D) from the midgut of larval P. interpunctella. The vertical bars are standard errors of the means of three replicates 


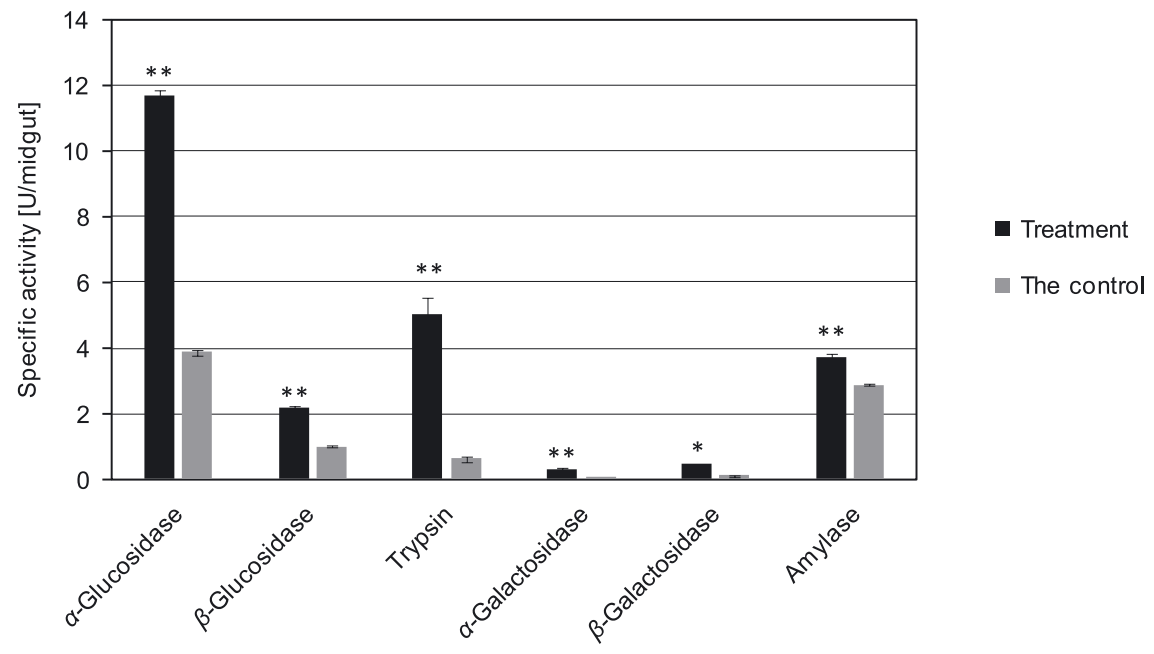

Fig. 2. Effect of the brain extract on the secretion of digestive enzymes in larval P. interpunctella $\left({ }^{* *} \mathrm{p}<0.01 ;{ }^{*} \mathrm{p}<0.05\right)$. The vertical bars represent standard errors of the means of three replicates
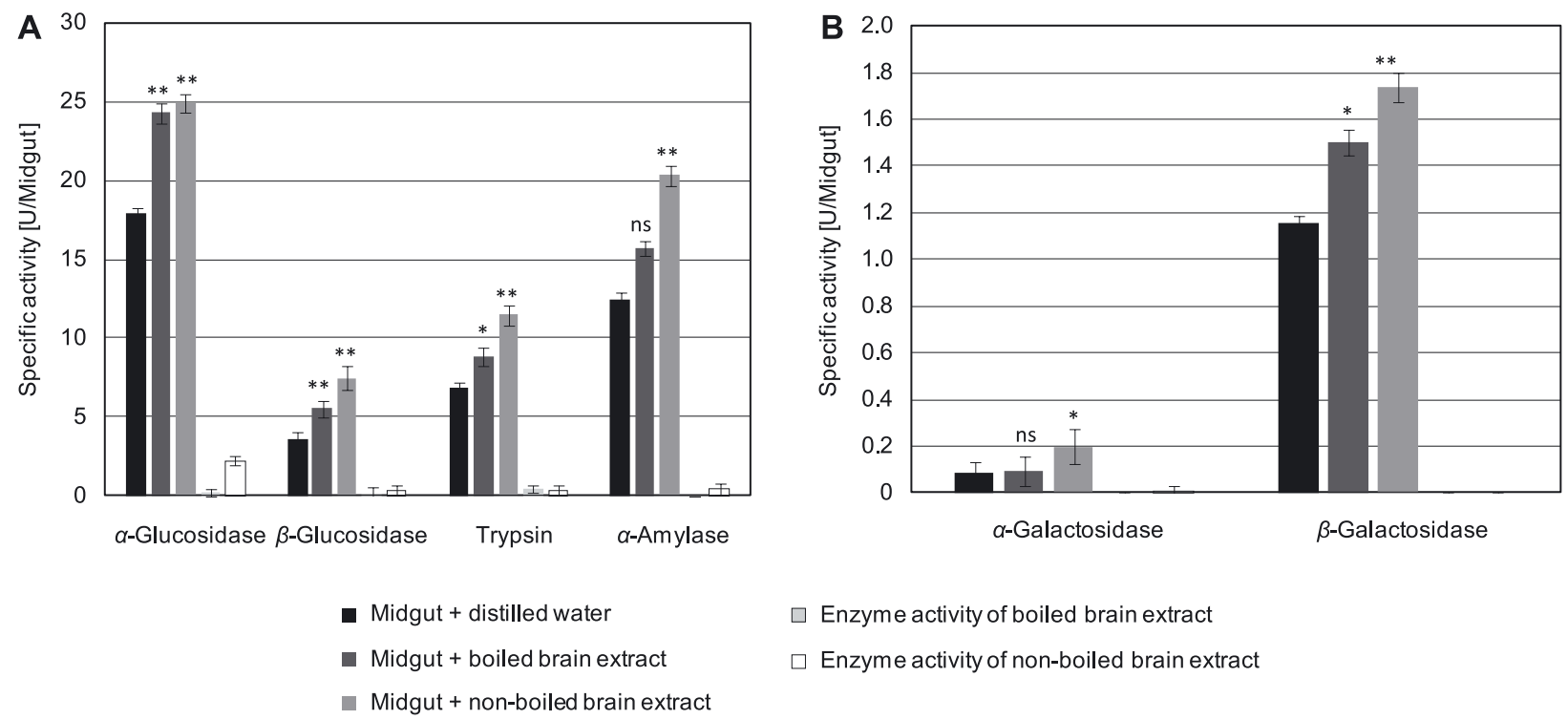

$\square$ Enzyme activity of boiled brain extract

$\square$ Enzyme activity of non-boiled brain extract

Fig. 3. Effect of high temperature (boiling water) on the brain extract effects on the secretion of digestive enzymes $\left[{ }^{* *} \mathrm{p}<0.01 ;{ }^{*} \mathrm{p}<0.05\right.$; ns (not significant): $\mathrm{p}>0.05]$. The vertical bars are standard errors of the means of three replicates

\section{Effect of the brain extract on hydrolase secretions}

The brain extract influenced the secretion of the hydrolases of the larval midgut of $P$. interpunctella (Fig. 2). The extract had a significant increasing impact on the secretion of $\alpha$-galactosidase $(\sim 15.6$-fold), trypsin $(\sim 7.9$-fold), $\beta$-galactosidase $(\sim 3.7$-fold $), \alpha$-glucosidase $(\sim 3$-fold), $\beta$-glucosidase ( 2.2-fold), and $\alpha$-amylase ( 1.3-fold).

\section{Temperature stability of the brain extract}

The enzyme activities were enhanced when the midgut was treated with the boiled and non-boiled brain extract, compared to the control (Fig. 3a, b). However, slightly higher enzyme activities were determined in the treatment of the midgut with the non-boiled brain extract than that of the boiled brain extract.
The brain extract boiled in a water bath for $1,3,5$, and 10 min showed a smaller enhancing impact on the secretion of $\alpha$-amylase, $\beta$-glucosidase, and trypsin than that of the non-boiled brain extract (Fig. 4a, b, c). In the treatment of the midgut with the brain extract boiled for $5 \mathrm{~min}$ ( $3 \mathrm{~min}$ in the case of $\beta$-glucosidase), the enzyme activities increased. When the brain extract was boiled more than $5 \mathrm{~min}$ ( $3 \mathrm{~min}$ in the case of $\beta$-glucosidase), it was less effective at enhancing the secretion of the enzymes.

\section{Dose-effect of the brain extract}

Incubation of the midgut preparations with different concentrations of the brain extract linearly enhanced the activity levels of $\alpha$-amylase $\left(R^{2}=0.94\right), \beta$-glucosidase $\left(R^{2}=\right.$ $=0.90)$ and trypsin $\left(R^{2}=0.97\right)$ levels in the lumen contents compared with the control (Fig. 5a, b, c). 

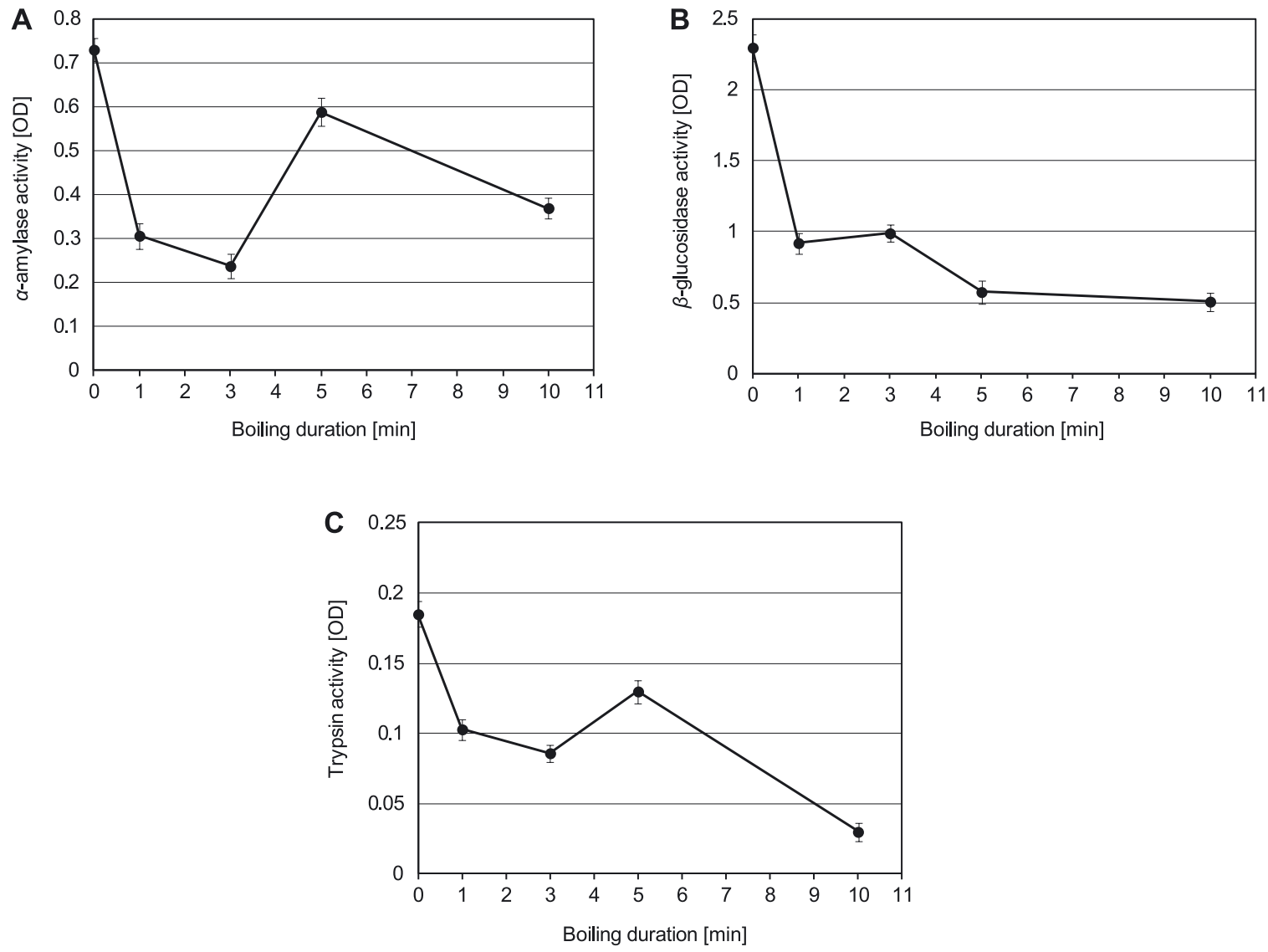

Fig. 4. Temperature stability of the brain extract and its effect on the secretion of $\alpha$-amylase (A), $\beta$-glucosidase (B), and trypsin (C) from the midgut larval $P$. interpunctella. The vertical bars are standard errors of the means of three replicates
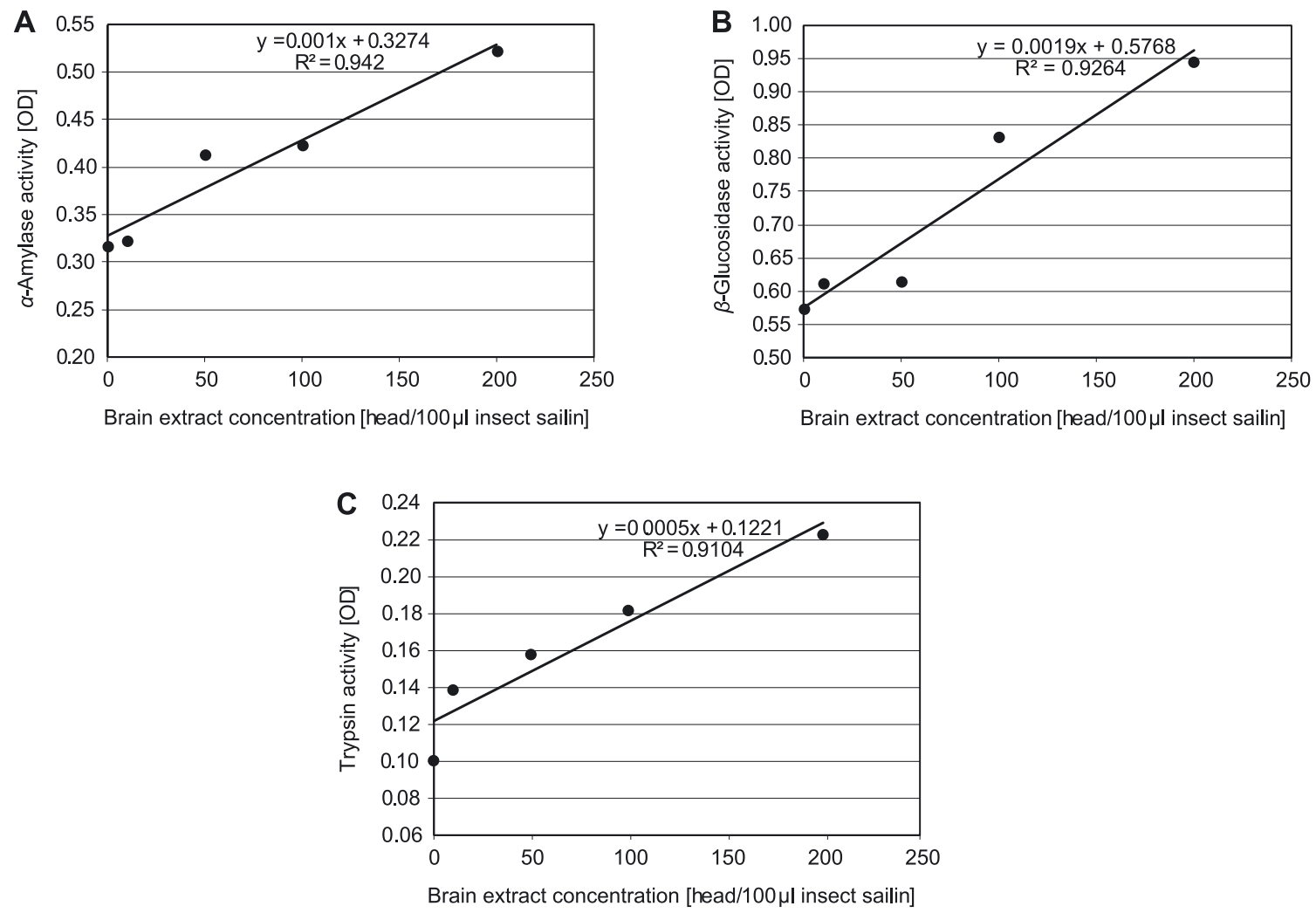

Fig. 5. Dose-response manner on the effect of different concentrations of the brain extract on the activity of $\alpha$-amylase (A), $\beta$-glucosidase (B), and trypsin (C) in midgut preparations of larval P. interpunctella 

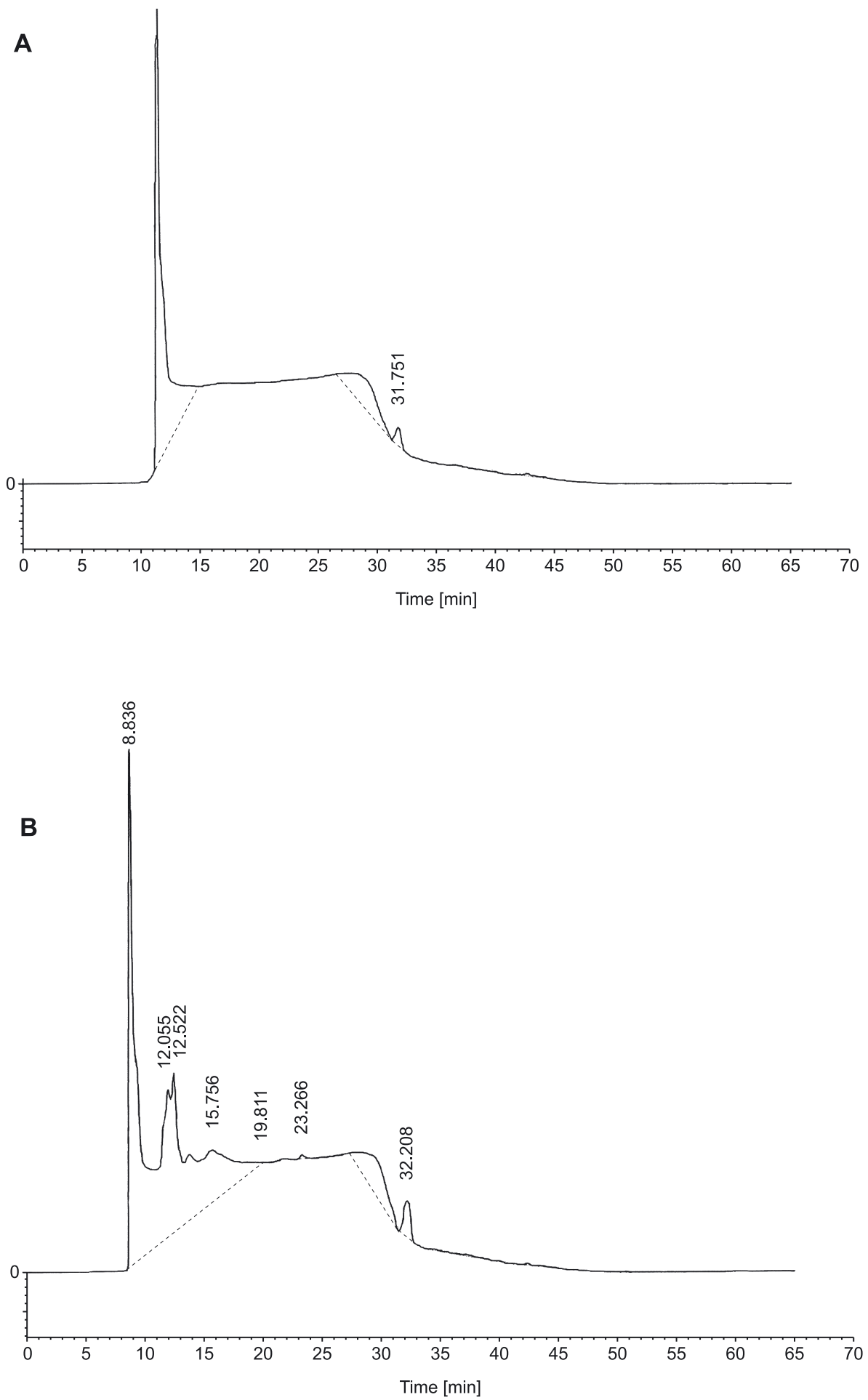

Fig. 6. HPLC chromatographs of the brain peptide treatment (A) and of the control (B)

\section{HPLC}

There were some differences in some points of the HPLC chromatographs of the brain extract (Fig. 6b) and the control (Fig. 6a). The different peaks were probably due to the putative brain peptides. The fractions corresponding to the peaks of interest were collected and used as treatment of the midgut. The peptide present in fraction No. 9 had a significant enhancing and declining effect on the activity levels of $\beta$-glucosidase and trypsin, respectively. The peptide present in fraction No. 13 showed a significant decreasing effect on trypsin activity in the midgut. Fraction No. 16 did not have any significant effect on the enzyme activity levels. Fraction No. 20 significantly decreased the activity of $\beta$-glucosidase (Fig. 7a). Fraction No. 24 significantly increased trypsin activity (Fig. 7b). 

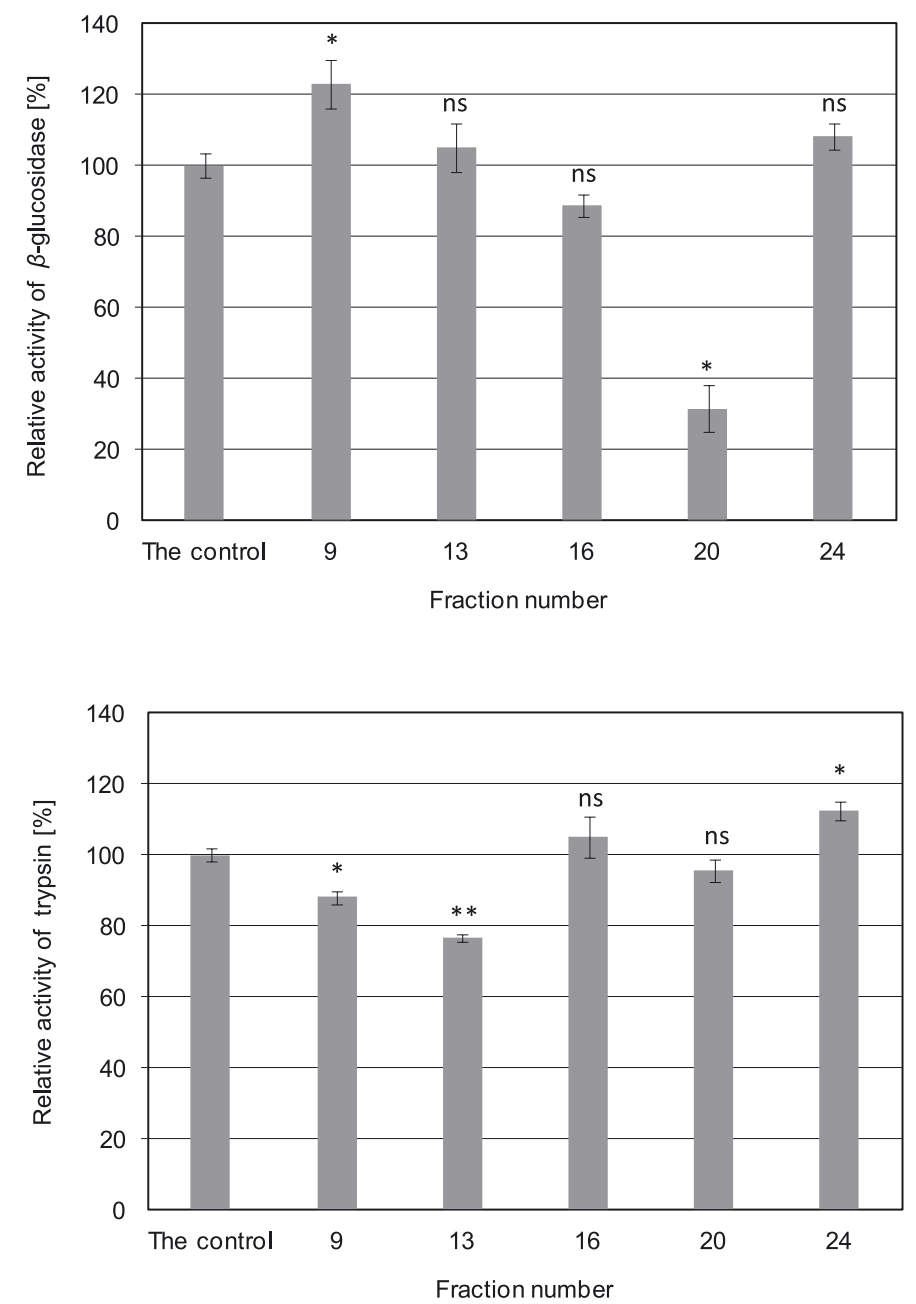

Fig. 7. Bioassay with the peptides obtained from HPLC fractionation. Effects of different fractions on the secretion of $\beta$-glucosidase (A), and trypsin (B) from midgut tissue of larval P. interpunctella [** $\mathrm{p}<0.01 ;{ }^{*} \mathrm{p}<0.05$; ns (not significant): $\left.\mathrm{p}>0.05\right]$. The vertical bars are standard errors of the means of three replicates

\section{Discussion}

Neurosecretions of the insect brain are involved in the regulation of digestive enzyme secretion (Prabhu and Sreekumar 1994). The present in vitro study has shown that incubation of the midgut of larval $P$. interpunctella with the larval brain extract causes an increase in activity of hydrolases in the midgut lumen. Muraleedharan and Prabhu (1979) have shown that extirpation of neurosecretory cells in Dysdercus cingulatus causes a decrease in the secretion of the protease and amylase enzymes. Harshini et al. (2003) have also observed that the brain extract obtained from the larvae of $O$. arenosella, stimulates release of $\alpha$-amylase from the midgut tissue of larvae, which is consistent with the findings of the present study. The increasing effect of the brain extract on the secretion of hydrolases from midgut cells is dose dependent. These results are consistent with an earlier study that showed that an increase in brain extract concentration caused an increase in the release of $\alpha$-amylase from the midgut tissue of larvae of $O$. arenosella (Harshini et al. 2003). Another study showed that a midgut peptide or probably hormone has a similar action in the larvae of Oryctes rhinoceros (Coleoptera: Scarabaeidae) (Sreekumar and Prabhu 1988).
In the present study, the stimulating factor of the secretion of the hydrolases from the $P$. interpunctella larva head was partially purified with $80 \%$ aqueous acetone. It was shown through HPLC analyses that there were several peaks in the peptide sample. In some related studies, some vertebrate-like gut peptides were separated and purified from the nervous system and tissues, such as the insulin-like material in Calliphora vomitoria (Diptera: Calliphoride) (Duve et al. 1979), and the gastrin-like peptide in Manduca sexta (Lepidoptera: Sphingidae) (Kramer et al. 1977), and C. vomitoria (Dockray et al. 1981). In one study on O. arenosella, an elution profile of OCF2:3 showed PK No. 3 and PK No. 4 separated by a time interval of 0.107 min (Harshini et al. 2003). In another study, it was observed that HPLC analyses of two midgut epithelial fractions called OMF1:1 and OMF3:1 stimulated enzyme release in the same insect species (Harshini and Sreekumar 2001). However, regarding the important functional role of these peptides, any conclusion without elucidation of all their various activities in different physiological and biological systems is impossible (Holman et al. 1987).

In this research, some peptides from the brain of larval $P$. interpunctella were extracted. The larval midgut in the presence of the extracted peptides was stimulated to produce more hydrolases including trypsin, galactosi- 
dases, glucosidases, and amylase. The stimulating factors ranged from 16 to $20 \mathrm{kDa}$. Identification of regulatory peptides can help us in designing new strategies for controlling stored-product insect pests.

\section{References}

Bernfeld P. 1955. Amylases, $\alpha$ and $\beta$. Methods Enzymol. 1: 149158.

Dockray G.J., Duve H., Thorpe A. 1981. Immunocytochemical characterization of gastrin/cholecystokinin-like peptides in the brain of the blow fly Calliphora vomitoria. Gen. Comp. Endocrinol. 45 (4): 491-496.

Duve H., Thorpe A., Lazarus N.R. 1979. Isolation of material displaying insulin-like immunological and biological activity from the brain of the blow fly, Calliphora vomitoria. Biochem. J. 184 (2): 221-227.

Duve H., Thorpe A. 1981. Gastrin/cholecystokinin (CCK)-like immunoreactive neurones in the brain of the blowfly, Calliphora eryfhrocephala (Diptera). Gen. Comp. Endocrinol. 43: 381-391.

Duve H., Thorpe A. 1984. Immunocytochemical mapping of gastrin/CCK-like peptides in the neuroendocrine system of the blowfly Calliphora vomitoria (Diptera). J. Cell Tissue Res. 237 (2): 309-320.

Hagstrum D.W., Subramanyam B. 1996. Integrated Management of Insects in Stored Products. Marcel Dekker, Inc., New York, 409 pp.

Harshini S., Sreekumar S. 2001. Isolation and partial purification of the digestive enzyme-release peptide hormone from the midgut of larvae of Opisina arenosella Walk. (Lepidoptera: Cryptophasidae). p. 191-197. In: “Advances in Entomology" (K. Muraleedharan, ed.). Association for Advancement of Entomology, Trivandrum, India, 359 pp.

Harshini S., Nachman R.J., Sreekumar S. 2002. Inhibition of digestive enzyme release by neuropeptides in the larvae of Opisina arenosella (Lepidoptera: Cryptophasidae). Comp. Biochem. Physiol. (B) 132 (2): 353-358.

Harshini S., Reshmi V., Sreekumar S. 2003. A brain peptide stimulates release of amylase from the midgut tissue of larvae of Opisina arenosella Walk. (Lepidoptera: Cryptophasidae). Neuropeptides 37 (3): 133-139.

Holman G.M., Cook B.J., Nachman R.J. 1987. Isolation, primary structure and synthesis of leucokinins VII and VIII: the final members of this new family of cephalomyotrophic peptides isolated from head extracts of Leucophaea maderae. Comp. Biochem. Physiol. (C) 88 (1): 31-34.

Holman G.M., Nachman R.J., Wright M.S. 1990. Insect peptides. Annu. Rev. Entomol. 35: 201-217.

Kramer K.J., Speirs R.D., Childs C.N. 1977. Immunological evidence for a gastrin-like peptide in insect neuroendocrine system. Gen. Comp. Endocrinol. 32: 423-426.

Kramer K.J. 1985. Vertebrate hormones in insects. p. 511-536. In: "Comprehensive Insect Physiology, Biochemistry and Pharmacology" (G.A. Kerkut, L.I. Gilbert, eds.). Pergamon Press, New York, 8536 pp.

Mohandass S., Arthur F.H., Zhu K.Y., Throne J.E. 2007. Biology and management of Plodia interpunctella (Lepidoptera:
Pyralidae) in stored products. J. Stored Prod. Res. 43 (3): 302-311.

Muraleedharan D., Prabhu V.K.K. 1979. Role of the median neurosecretory cells in secretion of protease and invertase in the red cotton bug, Dysdercus cingulatus. J. Insect Physiol. 25 (3): 237-240.

Phillips T.W., Berbert R.C., Cuperus G.W. 2000. Post-harvest integrated pest management. p. 2690-2701. In: “Encyclopedia of Food Science and Technology" (F.J. Francis, ed.). 2nd ed. Wiley Inc., New York, 2816 pp.

Prabhu V.K.K., Sreekumar S. 1994. Endocrine regulation of feeding and digestion in insects. p. 117-135. In: "Perspectives in Entomological Research" (O.P. Agarwal, ed.). Scientific Publishers, Jodhpur, India, 406 pp.

Ramzi S., Hosseininaveh V. 2010. Biochemical characterization of digestive $\alpha$-amylase, $\alpha$-glucosidase and $\beta$-glucosidase in pistachio green stink bug, Brachynema germari Kolenati (Hemiptera: Pentatomidae). J. Asia-Pacific Entomol. 13 (3): 215-219.

Sait S.M., Begon M., Thompson D.J., Harvey J.A., Hails R.S. 1997. Factors affecting host selection in an insect host-parasitoid interactions. Ecol. Entomol. 2 (1): 225-230.

Satake S.I., Masumura M., Ishizaki H., Nagata K., Kataoka H., Suzuki A., Mizoguchi A. 1997. Bombyxin, an insulin-related peptide of insects, reduces the major storage carbohydrates in the silkworm Bombyx mori. Comp. Biochem. Physiol. (B) 118 (2): 349-357.

Sreekumar S., Prabhu V.K.K. 1988. Probable endocrine role of midgut tissue in stimulation of digestive enzyme secretion in Oryctes rhinoceros (Coleoptera: Scarabaeidae). Proc. Indian Acad. Sci. 97 (1): 73-78.

Tabatabaei P.R., Hosseininaveh V., Goldansaz S.H., Talebi K. 2011. Biochemical characterization of digestive proteases and carbohydrases of the carob moth, Ectomyelois ceratoniae (Zeller) (Lepidoptera: Pyralidae). J. Asia-Pacific Entomol. 14 (2): 187-194.

Terhzaz S., O'Connell F.C., Pollock V.P., Kean L., Davies S.A., Veenstra J.A., Dow J.A.T. 1999. Isolation and characterization of a leucokinin-like peptide of Drosophila melanogaster. J. Exp. Biol. 202 (24): 3667-3676.

Verhaert P., Geysen J., De Loof A., Vandesande F. 1984. Immunoreactive material resembling vertebrate neuropeptides and neurophysins in the brain, suboesophageal ganglion, corpus cardiacum and corpus allatum of the dictyopteran Periplaneta americana L. J. Cell Tissue Res. 238: 55-59.

Verhaert P., De Loof A. 1985. Immunocytochemical localization of a methionine-enkephalin-resembling neuropeptide in the central nervous system of the American cockroach, Periplaneta americana L. J. Comp. Neurol. 239: 54-61.

Verhaert P., De Loof A. 1986. Substances resembling peptides of the vertebrate gonadotropin system occur in the central nervous system of Periplaneta americana L. Immunocytological and some biological evidence. Insect Biochem. 16 (1): 191-197.

Yui R., Fujita T., Ito S. 1980. Insulin-, gastrin-, pancreatic polypeptide-like immunoreactivity neurons in the brain of the silkworm, Bombyx mori. Biomedical Res. 1: 42-46. 